Received:

13 May, 2019

1st Revision:

29 May, 2019

Accepted:

2 June, 2019
UDC: 330.111 .42

DOI https://doi.org/10.26661/2522-1566/2019-2/08-01

*Corresponding author email: fitriayanti12@yahoo.com

\title{
THE WORK PLACEMENT EFFECT TOWARDS THE WORK ENVIRONMENT OF GRAND INDONESIA INDUSTRY COMPANY
}

FITRIA DAMAYANTI, Economic Department, Wiralodra University, West Java, Indramayu, Indonesia, ORCID ID: https://orcid.org/0000-0002-0699-454X

NURJANAH R, Economic Department, Wiralodra University, West Java, Indramayu, Indonesia, ORCID ID: https://orcid.org/0000-0003-3935-6242

Abstract. This study has purpose to find out the effect of work placement towards the work environment. Due to the hypothesis of the research, the right placement and position are able to help the company to achieve the goals. Afterward, the methods used are associative method and descriptive method. The indicator of work placement that is used in this study is synthesis of determining work location, determining work position, and assigning. The number of populations involving in this study is 268 and sample is 160 respondents. Then, the result of the study shows that the work placement based on Grand Indonesia Industry Company employees' responds in determining work location, work position and assignment indicators are 3896 which is categorized as good enough. Furthermore, the work environment in Grand Indonesia Industry Company based on Grand Indonesia Industry Company employees' responds on facilities and work implementation are 4034 which is categorized as very good. However, the analysis result of work placement correlation towards the work environment is $\mathrm{rX1}$. Y-0,22 included as low category. Originality and value of the research defined by the obtained results and discussion, according to which, it is supposed to increase the work placement for employees especially in assignments, determining the work position of employees so that employees are always passionate to work. It is also recommended to improve the work environment, especially in the implementation of work, work infrastructure so that employee performance can increase.

Practical and social implications of the research are added by the suggestion to improve the work environment, especially in the implementation of work, work infrastructure so that employee performance can increase.

Keywords: work placement, work environment, employee, company management, human resource, human resource management

JEL Classification: M52, M53, M54.

\section{INTRODUCTION}

Placement process is a process to determine how to get the competent employee as company necessary. It is due to the reason that right placement and position able to help the company to achieve the goals.

Grand Indonesia Industry Company is aware and full of consideration in locating the employee to make the employees to work efficiently and effectively as the company expected. Grand Indonesia Industry Company has a function to produce car seat cover. It means that the facilities and infrastructures should be noticed and maintained because the employee needs the accuracy, 
Fitria Damayanti and Nurjanah R (2019). "The work placement effect towards the work environment of Grand Indonesia Industry Company", Management and entrepreneurship: trends of development, 2 (08), pp. 8-17. doi: https://doi.org/10.26661/2522-1566/2019-2/08-01

expertise, and high concentration. I Komang Ardana (2012) state that placement is determining the location and position of the employee in implementation the job. Based on Veithzal Rivai Zainal (2014), placement is assignment or reassignment of the employee toward their new job. Both experts' opinion can be concluded that placement is a process to determine the location and position in assigning or reassigning the employee toward their new job.

The indicator of work placement that is used in this study is synthesis of both experts such as determining work location, determining work position, and assigning.

I Komang Ardana (2012) argue that work placement should consider some factors such as educational background, work experience, physic and mental health, marital status, age, sex, passion and hobby. Placement concept based on Veitzhal Rivai Zainal (2014) is promotion, transfer and demotion, and job posting programs. Edy Sutrisno (2016) claim that work environment is the entire of facilities and infrastructures around the employee which can influence the work implementation.

However, according to Alex S. Nitisemito (1984) cited by Danang Sunyoto (2015, p.38), work environment is described as anything around the employee that can influence the employee in doing their job.

Both experts' opinion can be synthesized that work environment is anything around the employee who are doing their job including the facilities and infrastructures that can influence the performance of the employee.

In this case, work environment indicators that are used in this study are the synthesis of both experts' opinion: work infrastructures, work facilities, and work implementation. Alex S. Nitisemito (1984, p.184) statement that is cited by Danang Sunyoto (2015) stated that work environment factors include the employee relationship, the level of work environment noise, the work rules, and the lighting. Sedarmayanti (2009) examine that work environment is divided into two types: physical of work environment and non-physical of work environment.

\section{METHODOLOGY}

According to Sugiyono (2017) method of study is defined as scientific way to get data with particular purposes and uses. In this study, the writers used a research method to ease them to do further research. The methods used in this study are descriptive and associative method. Descriptive method is a method which is portrayed and examined the problems of the study, while associative method knows the relationship between two variables or more in the sample that would be tested. Sugiyono (2017) claim that descriptive statistic is a statistic which is used to describe or portrayed the tested object by data sample or population without doing analysis and creating common conclusion.

Sugiyono (2017) examine that associative hypothesis is a statement which shows the presumption about the relationship between two variables or more. Besides that, Sugiyono (2017) also said that population is a generalization scope that consists of object/subject which have particular quality and characteristic which is determined by the researchers to be analyzed and concluded.

Afterward, population of this study is all the employee of PT. Grad Indonesia Industry which has 268 people in total. Based on Sugiyono (2017), sample is a part of the number and characteristic of the population. However, to know how many samples that would be used, the writer used the slovin formula as follows (Sugiyono, 2017). Sample that would be used is 160 of the population number 268 people.

$$
n=\frac{N}{1+N \cdot e^{2}}
$$


As compatible as the title of this study, there are two variables, the effect of work placement toward the work environment. Free variables are defined as independent variable that influences or being a cause of the changes or appearing the dependent variable (Sugiyono 2017). Independent variable of this study is work placement (X1) whereas dependent variable of this study is work environment (Y) which can be influence or being a cause of the independent variable exists.

Sugiyono (2017) claim that Likert scale is applied to measure the attitude, opinion, and perception of someone or groups about social phenomenon. Thus, by using Likert scale, variable that would be measured become variable indicator. Then, the indicator variable would be the guideline to arrange the instrument items which can be questions or statements.

Then, in collecting data field research is used, in which means if the writers do the research directly in the field to get the needed data. Meanwhile, in collecting data technique, there are three techniques used including interview, questionnaire, and observation (Sugiyono, 2017).

Collecting data is the writers' effort to collect numerical data or it can also be non-numerical data. In this study, the writers used primary data. According to Rully Indrawan and Poppy Yaniawati (2014), primary source is a direct source which gives the data for the data collector.

Data measurement based on category scale of Nur Indrayanto and Bambang Supomo (1999) as follows:

$$
\begin{array}{ll}
81 \%-100 \% & =\text { Very good } \\
61 \%-80 \% & =\text { Good } \\
41 \%-60 \% & =\text { Good enough } \\
21 \%-40 \% & =\text { Bad } \\
1 \%-20 \% & =\text { Very bad }
\end{array}
$$

The instrument validity of this study is an accurate degree which is defined by Sugiyono (2017) as accuracy degree between the real data that is happened to the object and the data that was reported by the researcher. Valid instrument means that the instrument that would be used is valid. Valid means that the instrument can measure what the things that should be measured (Sugiyono 2017). Hence, valid data is the different data or there is similarity between data collected and the real data of the tested object.

Instrument reliability testing can be conducted externally or internally. Externally, the testing can be conducting by test-retest (stability), equivalent, and both. Internally, instrument reliability can be tested by analyzing the consistency of instrument with particular technique. Normality test is used to make the data can be accounted for. It is important to know whether the data obtained is normal or not.

The definition of simple correlation analysis that was argued by Sugiyono (2017) is correlation technique used to find the relationship and prove the hypothesis of the relationship between two variables if the data is interval or ratio and the data source of both variable or more is the same. Further, multiple coefficient analysis is correlation technique that is used to two independent variables and one dependent variable (Sugiyono, 2017).

Determination coefficient analysis is a determination coefficient that is used to know how much the contribution of variable X1 (work placement) toward Y (work environment), as usual the data would be showed as percentage (\%).

$$
\mathrm{Kd}=\mathrm{r}^{2} \mathrm{x} \cdot 100 \%
$$

Means :

$K d=$ Determination coefficient

$r=$ Correlation coefficient 
Fitria Damayanti and Nurjanah R (2019). "The work placement effect towards the work environment of Grand Indonesia Industry Company", Management and entrepreneurship: trends of development, 2 (08), pp. 8-17. doi: https://doi.org/10.26661/2522-1566/2019-2/08-01

Here, hypothesis test analysis is defined as the way to determine whether the hypothesis would be accepted or not.

Hypothesis statistically can be written as follows:

Ho $: r \neq 0$ presumed there is effect between work placement and the employee performance.

$\mathrm{Ha}: \mathrm{r}=0$ presumed there is no effect between work placement and the employee performance.

$\mathrm{F}$ test is conducted to know whether the influence of $\mathrm{Xi}$ toward $\mathrm{Y}$ is significant or not. According to Sugiyono (2017), significance can be measured by using this formula:

$$
\frac{\mathrm{R}^{2} / \mathrm{k}}{F h=\left(1-R^{2}\right) /(n-k-1)}
$$

Means:

$\mathrm{R}=$ Multiple correlation coefficient

$\mathrm{k}=$ The number of Independent variables

$\mathrm{n}=$ The number of samples

To determine the value of $\mathrm{F}$, significance level used is $5 \%$ with the numerator $=\mathrm{k}$ and denominator (n-k-1), where " $n$ " is the number of samples and " $k$ " is the number of variables.

If $F_{\text {count }}>F_{\text {table }} S O$ Ho is rejected and Ha is accepted. However, if $F_{\text {count }}<F_{\text {table }}$ so Ho is accepted and $\mathrm{Ha}$ is rejected.

\section{RESULT AND DISCUSSION}

\section{The Employee Characteristics Based on The Sex}

The employee characteristics based on the sex of 160 employees in Grand Indonesia Industry Company can be known as follows:

Table 1

The employee characteristics based on the sex

\begin{tabular}{|c|c|c|}
\hline Sex & Total & $\%$ \\
\hline Male & 108 & 67,5 \\
\hline Female & 52 & 32,5 \\
\hline Total & 160 & 100 \\
\hline
\end{tabular}

Table above showed that according to the sex of 160 employee who is dominated by 108 males, $67,5 \%$, however females are 52 people, $32,5 \%$

\section{The Employee Characteristic Based on The Educational Level}

The employee characteristic based on the educational level can be seen in the table below:

The employee characteristic based on the educational level

\begin{tabular}{|c|c|c|}
\hline Educational Level & Total & $\%$ \\
\hline Senior High School & 150 & 93,75 \\
\hline Diploma & 1 & 0,625 \\
\hline Bachelor & 8 & 5 \\
\hline Master & 1 & 0,625 \\
\hline Doctor & 0 & 0 \\
\hline Total & 160 & 100 \\
\hline
\end{tabular}


According to the table above, it can be seen that the employee characteristic based on the educational level of 160 employee is 150 employee or $93,75 \%$ is the employee who graduated from senior high school, diploma is one person or $0,625 \%$. Bachelor is 8 people or $5 \%$ and master degree is one person or $0,625 \%$.

\section{Work Placement of Validity Instrument}

Table 3

Recapitulation of Validity Instrument Work Placement

\begin{tabular}{|c|c|c|c|}
\hline \multirow{2}{*}{ Number } & \multicolumn{2}{|c|}{ Validity } & \multirow{2}{*}{ Conclusion } \\
\cline { 2 - 3 } & $\begin{array}{c}\text { Correlation } \\
\text { Coefficient } \\
\text { (r count) }\end{array}$ & $\begin{array}{c}\text { Critical Value } \\
\text { (r table with significance } \\
\text { level of 5\%) }\end{array}$ & Valid \\
\hline 1 & 0,481 & 0,159 & Valid \\
\hline 2 & 0,423 & 0,159 & Valid \\
\hline 3 & 0,520 & 0,159 & Valid \\
\hline 4 & 0,487 & 0,159 & Valid \\
\hline 5 & 0,468 & 0,159 & Valid \\
\hline 6 & 0,504 & 0,159 & \\
\hline
\end{tabular}

Based on $r$ table of 0,159 with $5 \%$ indicator and the number of employees are 160, the data that was got such as above. This table above showed that 6 questions $r$ count $>r$ table 0,0159 . Thus, all questions are valid and can be used to analyze further.

\section{Work Environment of Validity Instrument}

Table 4

Recapitulation of Validity Instrument Work Environment

\begin{tabular}{|c|c|c|c|}
\hline \multirow[b]{2}{*}{ Number } & \multicolumn{2}{|r|}{ Validity } & \multirow[b]{2}{*}{ Conclusion } \\
\hline & $\begin{array}{c}\text { Correlation } \\
\text { Coefficient } \\
(\mathrm{r} \text { count })\end{array}$ & $\begin{array}{c}\text { Critical Value } \\
\text { (r table with } \\
\text { significance level of } \\
5 \%)\end{array}$ & \\
\hline 1 & 0,476 & 0,159 & Valid \\
\hline 2 & 0,496 & 0,159 & Valid \\
\hline 3 & 0,581 & 0,159 & Valid \\
\hline 4 & 0,576 & 0,159 & Valid \\
\hline 5 & 0,527 & 0,159 & Valid \\
\hline 6 & 0,528 & 0,159 & Valid \\
\hline
\end{tabular}

Based on $r$ table of 0,159 with 5\% indicator and the number of employees was 160, the data that was got such as above. This table above showed that 6 questions $r$ count $>r$ table 0,0159 . Thus, all questions are valid and can be used to analyze further.

\section{Reliability Instrument of Work Placement}

According to the reliability counting of work placement questionnaire, $\mathrm{r}=0,420$ with $\mathrm{N}=160$ and significance level $5 \%$ can be showed that $r$ table $=0,159$ so that, $r$ count $>r$ table $(0,543>0,159)$. Hence, it can be concluded that the questionnaire of work placement is reliable. 
Fitria Damayanti and Nurjanah R (2019). "The work placement effect towards the work environment of Grand Indonesia Industry Company", Management and entrepreneurship: trends of development, 2 (08), pp. 8-17. doi: https://doi.org/10.26661/2522-1566/2019-2/08-01

\section{Reliability Instrument of Work Environment}

According to the reliability counting of work environment questionnaire, $r=0,420$ with $N=160$ and significance level $5 \%$ can be showed that $r$ table $=0,159$ so that, $r$ count $>r$ table $(0,543>0,159)$. Hence, it can be concluded that the questionnaire of work environment is reliable.

\section{Variable Normality Test of Work Placement}

This test used Chi Quadrat as stated in the table 7.

Work Placement Normality

\begin{tabular}{|c|c|c|c|c|c|}
\hline INTERVAL & Fo & Fh & fo-fh & (fo - fh)*2 & (fo - fh)*2/fh \\
\hline $20-21$ & 17 & 4,32 & 12,68 & 25,36 & 5,87037037 \\
\hline $22-23$ & 38 & 21,648 & 16,352 & 32,704 & 1,510716925 \\
\hline $24-25$ & 61 & 54,608 & 6,392 & 12,784 & 0,234104893 \\
\hline $26-27$ & 28 & 54,608 & $-26,608$ & $-53,216$ & $-0,974509229$ \\
\hline $28-29$ & 14 & 21,648 & $-7,648$ & $-15,296$ & $-0,706577975$ \\
\hline $30-31$ & 2 & 4,32 & $-2,32$ & $-4,64$ & $-1,074074074$ \\
\hline Total & 160 & 161,152 & $-3,456$ & 2,556031 & 4,86003091 \\
\hline
\end{tabular}

According to the table, it can be seen that value of chi quadrat is 4,860 , whereas chi quadrat in the table with $\mathrm{dk}$ (freedom degree) $6-1=5$. Based on chi quadrat in the table, if $\mathrm{dk}=5$ in the $5 \%$ indicator, so the value of chi quadrat table is 11,070 . Yet, the number of chi quadrat counting is $4,860<$ chi quadrat table 11,079 , so, sample distribution is normal.

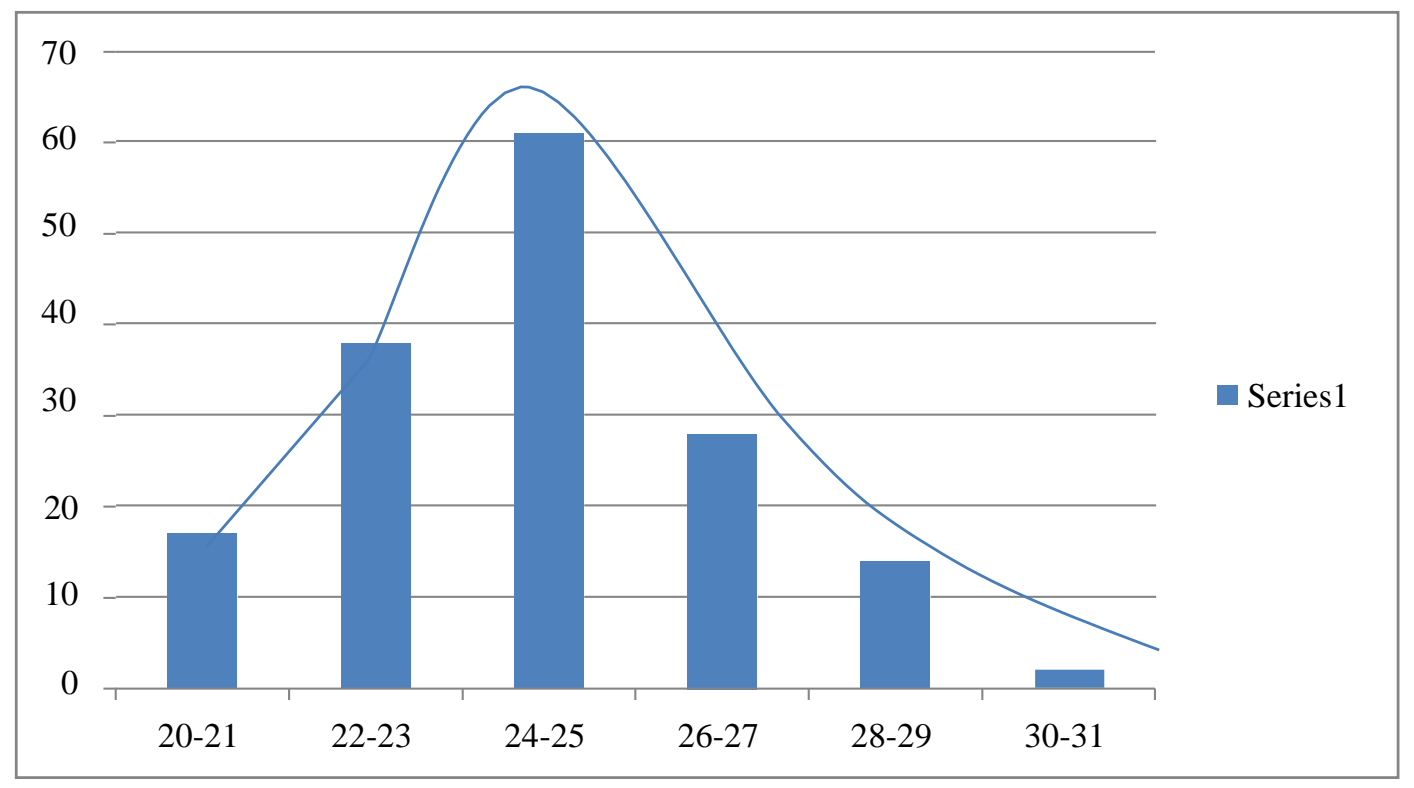

Figure 1. Work Placement Normality 


\section{Variable Normality Test of Work Environment}

Table 8

Work Environment Normality

\begin{tabular}{|c|c|c|c|c|c|}
\hline INTERVAL & Fo & Fh & fo-fh & (fo - fh)*2 & (fo - fh)*2/fh \\
\hline $20-21$ & 16 & 4,32 & 11,68 & 23,36 & 5,407407407 \\
\hline $22-23$ & 23 & 21,648 & 1,352 & 2,704 & 0,124907613 \\
\hline $24-25$ & 50 & 54,608 & $-4,608$ & $-9,216$ & $-0,168766481$ \\
\hline $26-27$ & 38 & 54,608 & $-16,608$ & $-33,216$ & $-0,608262526$ \\
\hline $28-29$ & 26 & 21,648 & 4,352 & 8,704 & 0,402069475 \\
\hline $30-31$ & 7 & 4,32 & 2,68 & 5,36 & 1,240740741 \\
\hline Total & 160 & 161,152 & $-3,456$ & 4,094096 & 6,398096229 \\
\hline
\end{tabular}

According to the table, it can be seen that value of chi quadrat is 6,398 , whereas chi quadrat in the table with $\mathrm{dk}$ (freedom degree) $6-1=5$. Based on chi quadrat in the table, if $\mathrm{dk}=5$ in the $5 \%$ indicator, so the value of chi quadrat table is 11,070 . Yet, the number of chi quadrat counting is $6,398<$ chi quadrat table 11,079 , so, sample distribution is normal.

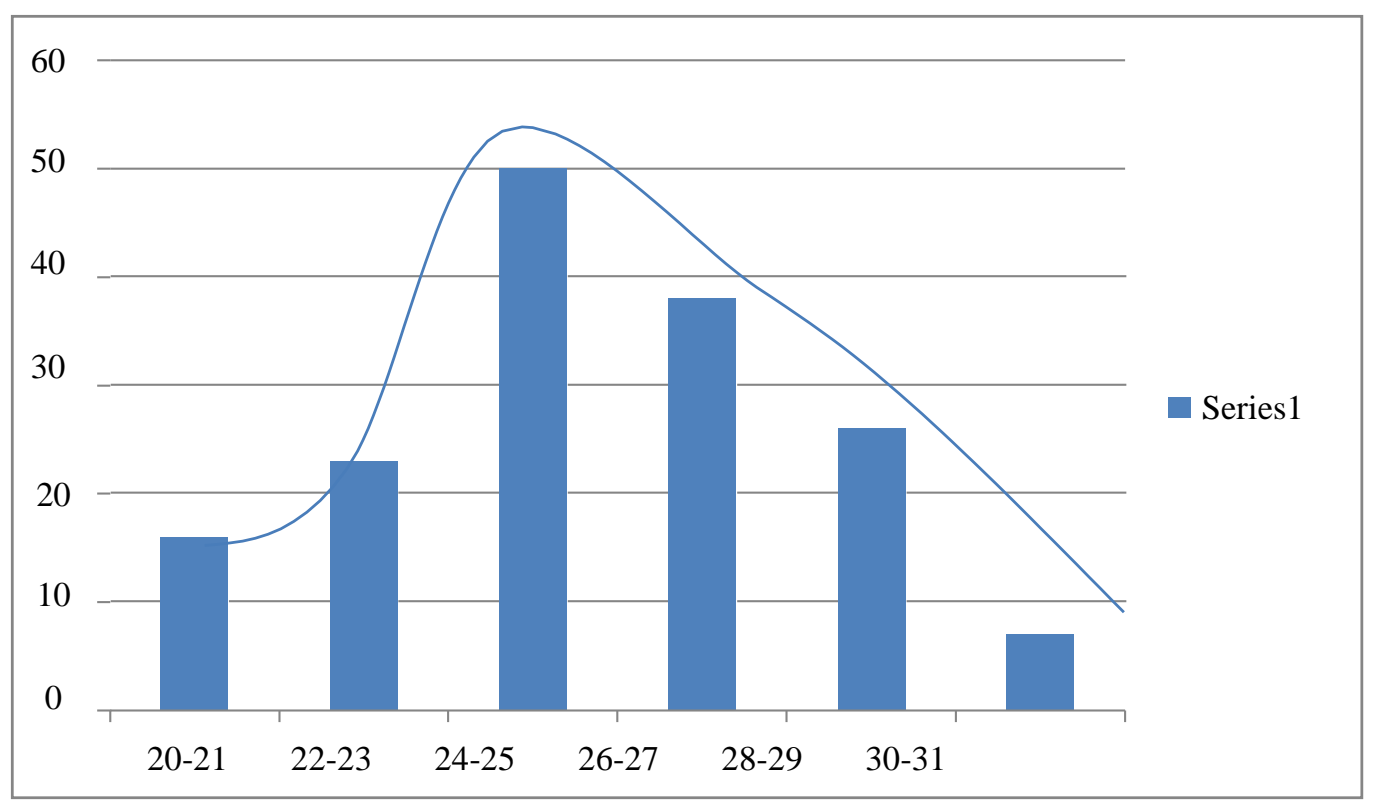

Figure 2. Work Environment Normality

\section{Work Placement Correlation Analysis toward Work Environment}

According to the correlation counting, it can be concluded that the value of $\mathrm{r}$ count is 0,212 included the low category, means that there is positive direct effect.

\section{Determination Coefficient of X1 toward Y}

According to the counting, it can be concluded that work placement toward work environment has significance value of $4,4944 \%$. However, the rest of $95,5056 \%$ is influenced by another factors that is not analyzed. 
Fitria Damayanti and Nurjanah R (2019). "The work placement effect towards the work environment of Grand Indonesia Industry Company", Management and entrepreneurship: trends of development, 2 (08), pp. 8-17. doi: https://doi.org/10.26661/2522-1566/2019-2/08-01

\section{The Hypothesis of $\mathrm{X} 1$ toward $\mathrm{Y}$}

To know further about the phenomenon in the sample of population, thus T-Test is used and based on the result, it showed that $\mathrm{t}_{\text {count }}=2,726$ however, $\mathrm{t}_{\text {table }}$ with $5 \%$ level of accuracy and freedom degree $\mathrm{dk}=\mathrm{n}-2=160-2=158$, so $\mathrm{t}_{\text {table }}=1,654$. Because $\mathrm{t}_{\text {count }}$ is bigger than $\mathrm{t}_{\text {table }} 2,726>1,654$.

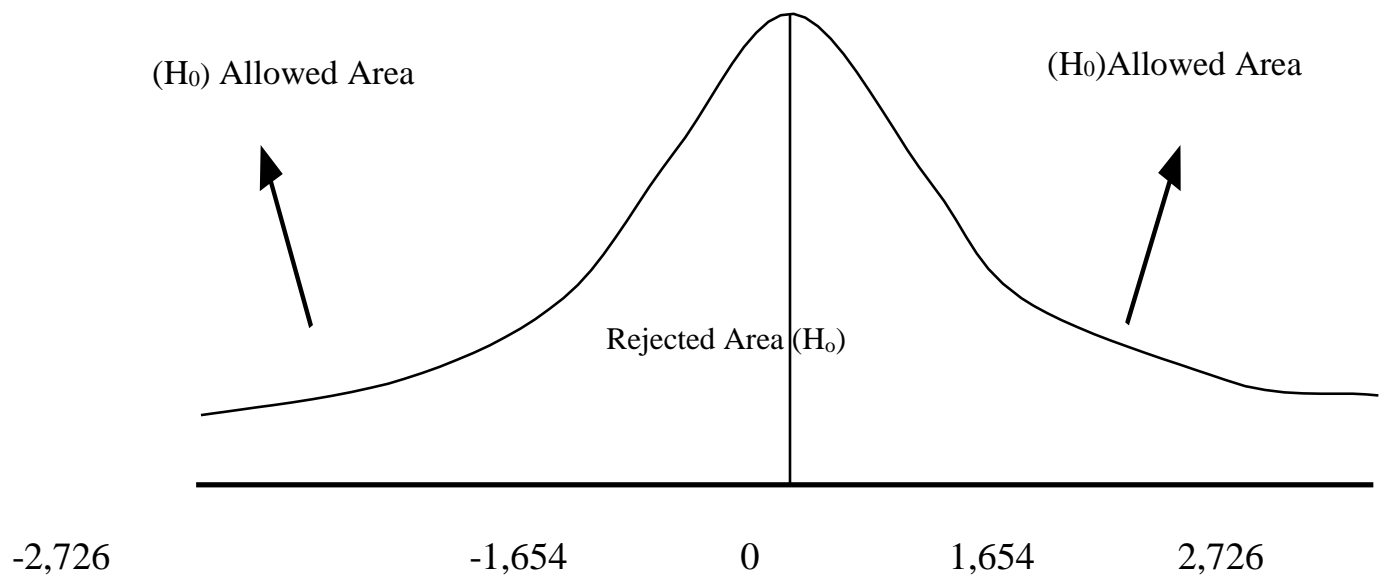

Figure 3. Hypothesis Analysis between Two Parties X1 toward Y

\section{CONCLUSIONS}

According to the result and discussion of this study, thus, it can be concluded that the work placement in Grand Indonesia Industry Company based on the result analysis such as determining work location, determining work position, and determining job description is categorized as good category. Afterward, the work environment of Grand Indonesia Industry Company based on the result analysis such as work facilities, infrastructures, and implementation is categorized as very good category. At last, the correlation between work placement and work environment categorize in low category which means that there is direct positive influence and significant as well.

\section{SUGGESTION}

According to the result and discussion of this study, there will be some suggestions such as it is supposes to increase the work placement for employees especially in assignments, determining the work position of employees so that employees are always passionate to work. Afterward, it is recommended to improve the work environment, especially in the implementation of work, work infrastructure so that employee performance can increase.

\section{REFERENCES}

Ardana, I Komang et al. (2012). Manajemen Sumber daya Manusia. Yogyakarta: Graha Ilmu (in Indonesian).

Chelliah, J. (2010). "Power Sharing in Progressive Discipline: New Rules of Engagement Arising from an Australian Perspective", Contemporary Management Research, Vol. 6, No. 2, pp. 91110.

Fadilah, Asri Nur et al. (2013). "Pengaruh Penempatan Pegawai Terhadap Kinerja (Studi Kasus Pada Pegawai Sekretariat Daerah Kabupaten Gresik)“, Jurnal Administrasi Publik, Vol. 1, No. 5, pp. 847-852 (in Indonesian). 
Hasibuan, Malayu (2007). Manajemen Sumber Daya Manusia, Edisi Revisi. Jakarta: Bumi Aksara (in Indonesian).

Indrawan, R. and Yaniawati, P. (2014). Metode Penelitian Kuantitatif, Kualitatif, dan Campuran untuk Manajemen, Pembangunan dan Pendidikan. Bandung: Refika Aditama (in Indonesian).

Junialdi, Andiyan (2013). Pengaruh Deskripsi Pekerjaandan Lingkungan Kerja Terhadap Kinerja Karyawan di Lembaga Penerbangan dan Antariksa Nasional (LAPAN) Bandung. Skripsi: Universitas Pasundan (in Indonesian).

Linge, Teresia Kavoo and James K Kiruri (2013). "The Effect of Placement Practices on Employee Performance in Small Service Firms in the Information Technology Sector in Kenya", International Journal of Business and Social Science, Vol. 4, No. 15, p. 213

Mangkunegara, A. A. (2013). Manajemen Sumber Daya Manusia Perusahaan. Bandung: PT Remaja Rosdakarya (in Indonesian).

Marwansyah (2014). Manajemen Sumber Daya Manusia. Bandung: Alfabeta (in Indonesian).

Sarsono, and Y Djoko Suseno (2012). "Pengaruh Deskripsi Pekerjaan dan Pengembangan Karir Terhadap Prestasi Kerja Dengan Kepuasan Kerja Sebagai Variabel Moderasi”, Jurnal Manajemen Sumberdaya Manusia, Vol. 6, No, 2, p. 140 (in Indonesian).

Sedarmayanti (2009). Sumber Daya Manusia dan Produktivitas Kerja. Jakarta: Mandar Maju (in Indonesian).

Sinambela Poltak (2012). Kinerja Pegawai Teori Pengukuran dan Implikasi. Yogyakarta: Graha Ilmu (in Indonesian).

Situmorang, Syafrizal Helmi and Muslich, Lufti (2012). Analisis Data, Edisi kedua, Medan: USU Press (in Indonesian).

Sugiyono (2017). Statistik Untuk Penelitian. Bandung : Alfa Beta (in Indonesian).

Sunyoto, Danang (2015). Manajemen dan Pengembangan Sumber Daya Manusia. Yogyakarta : CAPS (Center Of Academic Publishing Service) (in Indonesian).

Sutrisno, Edy (2016). Manajemen sumber daya manusia. Jakarta: Kencana Prenada Media Group (in Indonesian).

Umar, Husein (2014). RisetPemasaran dan PrilakuKonsumen.Jakarta. PT. GramediaPustaka Utama (in Indonesian).

Wibowo (2016). Manajemen Kinerja. Depok: PT. Raja Grafindo Persada (in Indonesian).

Yahya, Khulida Kirana (2009). "Linking Organizational Structure, Job Characteristic, and Job Performance Constructs: A Proposed Framework", International Journal of Business and Management, Vol. 4, No. 3, p. 151.

Zainal, V. R. (2014). Manajamen sumber daya manusia untuk perusahaan: Dari teori ke praktik. Jakarta: PT. Raja Grafindo Persada (in Indonesian).

\section{ВПЛИВ ОРГАНІЗАЦІЇ РОБОЧИХ МІСЦЬ НА РОБОЧЕ СЕРЕДОВИЩЕ КОМПАНІЇ «GRAND INDONESIA INDUSTRY COMPANY»}

FITRIA DAMAYANTI, економічний факультет, університет Віралодра, Західна Ява, Індрамаю, Індонезія

NURJANAH R, економічний факультет, університет Віралодра, Західна Ява, Індрамаю, Індонезія

Дане дослідження має на меті з'ясувати вплив процесу організації робочих місць на робоче середовище компанії. Відповідно гіпотезі дослідження, ефективна організація робочих місць та їх розташування на виробництві здатні допомогти компанії досягти поставлених цілей. Для досягнення зазначеної мети використовуються наступні методи наукового дослідження: асоціативний метод та метод опису. У дослідженні використовується індикатор робочого місця, який являє собою синтез визначення 
Fitria Damayanti and Nurjanah R (2019). "The work placement effect towards the work environment of Grand Indonesia Industry Company", Management and entrepreneurship: trends of development, 2 (08), pp. 8-17. doi: https://doi.org/10.26661/2522-1566/2019-2/08-01

розташування робочого місця, визначення робочого місця безпосередньо і його призначення. Число груп населення, які беруть участь в цьому дослідженні, становить 268, а вибірка - 160 респондентів. Результати дослідження доводять, що розподіл робочих місць, заснований на відповідях співробітників «Grand Indonesia Industry Company» при визначенні місця розташування роботи, робочих місць і показників призначення, становить 3896, що класифікується як достатньо добре. Крім того, робоче середовище в «Grand Indonesia Industry Company», засноване на відповідях про об'єкти і виконання робіт, складає 4034, що відноситься до категорії дуже добрих. Проте, результат аналізу кореляції розміщення роботи 3 робочим середовищем - rX1. Y-0,22 позначений як низька категорія. Відповідно до результатів даного дослідження, передбачається необхідність в збільшенні та вдосконаленні робочого простору співробітників, особливо в інструкціях по диверсифікації робочих місць 3 тим, щоб співробітники завжди були захоплені роботою. Практичне і соціальне значення дослідження доповнюються пропозицією і рекомендаціями поліпшити робочий простір, a також робочу інфраструктуру на досліджуваному підприємстві, 3 тим, щоб підвищити продуктивність співробітників.

Ключові слова: організація робочого місця, робоче середовище, працівник, керівництво компанії, людські ресурси, управління персоналом.

\section{ВЛИЯНИЕ ОРГАНИЗАЦИИ РАБОЧИХ МЕСТ НА РАБОЧУЮ СРЕДУ КОМПАНИИ «GRAND INDONESIA INDUSTRY COMPANY»}

FITRIA DAMAYANTI, экономический факультет Университета Виралодра, Западная Ява, Индрамаю, Индонезия

NURJANAH R, экономический факультет Университета Виралодра, Западная Ява, Индрамаю, Индонезия

Данное исследование имеет целью выяснить влияние процесса организации рабочих мест на рабочую среду компании. Согласно гипотезе исследования, эффективная организация рабочих мест и их расположение на производстве способны помочь компании достичь поставленных целей. Для достижения указанной цели используются следующие методы научного исследования: ассоциативный метод и метод описания. В исследовании используется индикатор рабочего места, который представляет собой синтез определения расположения рабочего места, определения рабочего места непосредственно и его назначения. Число групп населения, участвующих в этом исследовании, составляет 268, а выборка - 160 респондентов. Результаты исследования доказывают, что распределение рабочих мест, основанное на ответах сотрудников «Grand Indonesia Industry Company» при определении местоположения работы, рабочих мест и показателей назначения, составляет 3896, что классифицируется как достаточно хорошее. Кроме того, рабочая среда в «Grand Indonesia Industry Company», основанная на ответах об объектах и выполнении работ, составляет 4034, что относится к категории очень хороших. Тем не менее, результат анализа корреляции размещения работы с рабочей средой - rX1. Y-0,22 обозначен как низкая категория. Ценность исследования определяется полученными результатами, согласно которым предполагается увеличить и усовершенствовать рабочее пространство сотрудников, особенно в инструкциях по диверсификации рабочих мест с тем, чтобы сотрудники всегда были увлечены работой. Практическое и социальное значения исследования дополняются предложением и рекомендациями улучшить рабочее пространство, а также рабочую инфраструктуру на исследуемом предприятии, с тем, чтобы повысить производительность сотрудников.

Ключевые слова: организация рабочего места, рабочая среда, работник, руководство компании, человеческие ресурсы, управление персоналом. 